\title{
Manajemen Wisata Religius Kesultanan Banten (Bauran Komunikasi Pemasaran dalam Meningkatkan Jumlah Wisatawan)
}

\author{
Annisarizki \\ Fakultas IImu Sosial IImu Politik dan IImu Hukum Universitas Serang Raya Banten \\ Email: annisarizzkii@gmail.com \\ Media Sucahya \\ Fakultas IImu Sosial IImu Politik dan IImu Hukum Universitas Serang Raya Banten \\ Email: memetsumemet@gmail.com
}

\begin{abstract}
ABSTRAK
Penelitian ini bertujuan untuk mengkaji manajemen wisata religius Kesultanan Banten Lama dengan model manajemen bauran pemasaran dalam rangka memperkuat branding objek ziarah. Untuk mencapai tujuan tersebut, identifikasi masalah dalam studi ini ialah konsep manajemen wisata religius guna meningkatkan pengelolaan Kesultanan Banten Lama dan proses bauran komunikasi pemasaran yang berkaitan dengan penguatan citra. Penelitian ini merupakan riset kualitatif, yaitu menggambarkan sebuah perspektif atau informasi dari suatu masalah. Tipe penelitian ini adalah analisis kualitatif yang bersifat sistemis, subjektivis dan analitis. Teknik pengumpulan data penelitian ini menggunakan wawancara mendalam, observasi, dan studi pustaka. Hasil penelitian ini menunjukkan bahwa manajemen pariwisata Kesultanan Banten sudah menerapkan bauran komunikasi pemasaran, kecuali pemasaran langsung. Salah satu faktor yang menyebabkan bauran komunikasi pemasaran yang dilakukan belum berjalan maksimal ialah belum selesainya program revitalisasi Banten Lama (2018-2020) yang bertujuan menata ulang Kawasan Banten Lama agar sesuai dengan standar nasional.
\end{abstract}

Kata Kunci: Bauran komunikasi pemasaran, pariwisata, wisata religius, Banten

\section{ABSTRACT}

This study aims to analyze the management of the Old Banten Sultanate religious tourism with a marketing mix management model in order to strengthen the branding of the pilgrimage object. Identification of the problem in this study is the concept of religious tourism management which aims to improve the management of the Old Banten Sultanate and the marketing communication mix process to strengthen the image of the Banten Sultanate. This research is qualitative research. The characteristic of this research is systemic, subjectivist and analytic. The data collection technique of this study uses in-depth interviews, observations, and literature studies. The results of this study indicate that the tourism management of the Sultanate of Banten has implemented marketing communication mix, except direct marketing. One of the factors that caused the implementation of the marketing communication mix not optimal is the completion of the Banten Lama's revitalization program (2018-2020) which aims to rearrange the Old Banten Region to conform national standards.

Keywords: Marketing communication mix, tourism, religious tourism, Banten

Citation : Annisarizki dan Media Sucahya. (2018). "Manajemen Wisata Religius Kesultanan Banten (Bauran Komunikasi Pemasaran dalam Meningkatkan Jumlah Wisatawan)". Nyimak Journal of Communication, 2(2): 187-205. 


\section{PENDAHULUAN}

Indonesia mempunyai potensi pariwisata berbasis religi yang sangat lengkap dan diakui dunia. Mayoritas masyarakat Indonesia yang beragama Islam turut berkontribusi dalam membentuk segmen pariwisata berbasis religi. Dengan semakin maraknya wisata ziarah, tren kepariwisataan pun mulai bergeser dari sun, sand and sea, menjadi serenity, sustainability and spirituality.

Tujuan objek wisata religi yang selalu dikunjungi wisatawan di antaranya adalah petilasan orang suci, makam pemimpin yang diagungkan, gunung, bukit, tempat-tempat tertentu yang dianggap keramat, dan tempat pemakaman pemimpin yang dianggap gaib. Tujuan wisatawan mengunjungi objek wisata religi tersebut adalah untuk mendapatkan pengetahuan, kenikmatan dan kepuasan dalam menghayati keagamaan dan pemantapan rohani. Mereka melakukan zikir, bersalawat pada Nabi, dan membaca Alquran.

Di Indonesia, wisata religi memiliki kekhasan, yaitu mengunjungi tempat yang dianggap keramat. Makam ulama diziarahi karena semasa hidupnya ulama mempunyai karomah, menjalankan taraf spiritual yang tinggi, bisa melakukan sesuatu hal yang luar biasa, dan mampu melampaui pengalaman manusia biasa. Ulama juga dinilai memiliki kesaktian dan dapat melakukan apa pun untuk membasmi kejahatan.

Pemerintah sendiri menyebutkan bahwa wisata religi termasuk bagian dari objek wisata yang diakui dan dikembangkan. Undang-Undang Nomor 10 Tahun 2009 tentang Kepariwisataan (Pasal 4) menyebutkan bahwa pariwisata bertujuan untuk meningkatkan kesejahteraan rakyat, melestarikan alam, lingkungan, dan sumberdaya serta memajukan kebudayaan. Sedangkan Pasal 6 menyebutkan pembangunan kepariwisataan dilakukan melalui pelaksanaan rencana pembangunan kepariwisataan dengan cara memperhatikan keanekaragaman, keunikan, dan kekhasan budaya, alam, dan kebutuhan manusia untuk berwisata.

Provinsi Banten termasuk wilayah yang mempunyai kekayaan objek wisata yang cukup beragam, mulai dari pantai, Taman Nasional Ujung Kulon, objek wisata religius dan kuliner. Dinas Pariwisata Provinsi Banten berkepentingan melakukan promosi tujuan wisata untuk memengaruhi berbagai pihak agar tertarik pada objek-objek wisata sehingga jumlah wisatawan ke Banten meningkat. Melakukan promosi sangat penting, karena promosi tidak hanya sekadar berkomunikasi atau menyampaikan informasi, tapi juga menciptakan suasana di mana pelanggan bersedia memilih dan memiliki produk. Tujuan promosi adalah memberikan informasi, membujuk, menciptakan kesan; promosi merupakan alat untuk mencapai tujuan (Sulaksana, 2007). Selain itu, promosi bertujuan menjaga kesetiaan pelanggan, menjaga kestabilan penjualan saat terjadi kelesuan pasar, membedakan dan 
mengunggulkan produk dibanding produk pesaing, dan membentuk citra produk di mata konsumen sesuai dengan yang diinginkan.

Situs Kesultanan Banten, yang dikenal dengan sebutan Makam Sultan Banten (Sultan Maulana Hasanudin), merupakan salah satu objek wisata religi di Banten. Situs Kesultanan Banten pada abad ke-16 berada di Kecamatan Kasemen Kota Serang. Dalam kawasan ini terdapat Makam Sultan Maulana Hasanudin, Musium Situs Kepurbakalaan Banten Lama, Keraton Surosowan, Masjid Agung, Benteng Speelwijk, Istana Kaibon, Vihara Avalokitesvara dan Pelabuhan Karangantu. Semua situs tersebut berada di dalam satu kawasan.

Menurut Yoeti (2008), Kesultanan Banten sudah memenuhi persyaratan sebagai tempat pariwisata karena memenuhi tiga unsur. Pertama, something to see, yaitu daerah tersebut harus dapat dilihat dan disaksikan. Juga harus ada atraksi wisata yang berbeda dengan apa yang dimiliki oleh daerah lain. Makam Sultan Maulana Hasanuddin berada di lingkungan Masjid Agung Banten Lama, makam keluarga kesultanan Banten, menara masjid Agung Banten Lama, dan petilasan. Sedangkan atraksi yang ada di Kesultanan Banten antara lain Peringatan Maulid Nabi Besar, Khaul (memperingati hari kematian ulama), dan Istighosah atau doa bersama yang dipimpin ulama. Menurut Yoeti (1997), atraksi adalah sesuatu yang dapat dilihat melalui pertunjukan yang khusus diadakan untuk wisatawan. Atraksi ditampilkan berupa wujud peristiwa atau kejadian, baik yang terjadi secara berkala maupun sekali saja, baik bersifat tradisional maupun yang sudah dilembagakan dalam masyarakat modern. Atraksi memberi nilai positif bagi wisatawan untuk mengunjungi, menyaksikan, dan menikmati sehingga mampu memberi kepuasan maksimal bagi para wisatawan yang telah bergerak untuk mengunjunginya (Damardjati, 1995).

Kedua, something to do, yaitu lokasi wisata punya beberapa kegiatan yang dapat dilakukan sehingga wisatawan bisa betah berlama-lama untuk tinggal di lokasi tersebut. Kesultanan Banten memiliki kegiatan yang bisa membuat peziarah melakukan sesuatu, misalnya zikir dan mengaji di hadapan makam Sultan Maulana Hasanudin, melihat arsitektur masjid Agung Banten, melihat petilasan keluarga Kesultanan Banten. Ketiga, something to buy, yaitu daerah tersebut harus memiliki fasilitas berbelanja, khususnya barang-barang souvenir dari kerajian masyarakat lokal sebagai oleh-oleh untuk dibawa pulang. Kesultanan Banten menyediakan fasilitas belanja yang dikelola masyarakat, berbentuk kios yang mengelilingi lokasi Kesultanan Banten. Berbagai cinderamata yang bisa ditemui antara lain tasbih,kopiah, sajadah, parfum, kaos, emping, boneka, dan tas.

Perilaku para wisatawan yang mengunjungi Makam Sultan Maulana Hasanudin dan Makam Ulama di Banten adalah aktivitas manusia dalam melakukan komunikasi kepada tuhan, disebut juga komunikasi ritual. Ada lima tujuan manusia berkomunikasi dengan tuhan: 
meningkatkan iman dan takwa, peningkatan kualitas ibadah, peningkatan kualitas akhlak, tercapainya kedamaian hakiki, keselamatan dunia dan akhirat (Saefulah, 2007). Oleh sebab itu, berziarah ke makam ulama ialah implementasi komunikasi ritual untuk meningkatkan iman dan takwa, yang dilakukan misalnya melalui salat, membaca Alquran, zikir, berdoa, dan bertafakur.

Berdasarkan pemaparan singkat di atas, penelitian ini bertujuan untuk mengkaji manajemen wisata religius Kesultanan Banten Lama dengan model manajemen bauran pemasaran dalam rangka memperkuat branding objek ziarah. Untuk mencapai tujuan tersebut, identifikasi masalah dalam studi ini adalah konsep manajemen wisata religius guna meningkatkan pengelolaan Kesultanan Banten Lama dan proses bauran pemasaran komunikasi tentang penguatan citra sebagai lokus ziarah.

\section{KERANGKA TEORI}

\section{Wisata Religius dalam Perspektif Komunikasi}

Wisata religi dengan mengunjungi makam keramat sudah menjadi bagian dalam tradisi masyarakat Indonesia sejak lama. Religi atau sistem kepercayaan dan bahasa merupakan salah satu budaya, kesenian, sistem pengetahuan, perlengkapan hidup, dan mata pencaharian. Untuk menjalankan aktivitas kebudayaan memerlukan komunikasi. Ziarah merupakan proses menjalankan kebudayaan dengan menggunakan bahasa, yaitu membaca doa dan berzikir. Dengan demikian, proses komunikasi dengan menggunakan bahasa ialah sebagai proses budaya; melakukan ziarah dengan melakukan zikir, berdoa, dan menabur bunga merupakan manifestasi komunikasi sebagai proses beribadah.

Kebudayaan merupakan sebuah gagasan ide yang berada dalam pikiran manusia dan bukanlah sebuah gejala yang tersusun atas kebiasaan dan perilaku manusia. Bentuk kebudayaan terdiri dari norma, nilai, dan larangan melakukan suatu tindakan dalam hal menghadapi situasi lingkungan sosial dan kebudayaan di mana masyarakat itu menetap atau tinggal (Surahman, 2016).

Makam yang dikeramatkan adalah mitos yang dibentuk di dalam sistem budaya. Mitos adalah realitas sosial yang juga memiliki kepentingan sosial. Dengan membangun mitos tersebut masyarakat di sekitarnya juga dapat menerima manfaat ekonomi (Anwar, Hamid \& Topowijono, 2017; Widagdo \& Rokhlinasari, 2017; Rohman \& Fauzi, 2016). Sementara itu, mitos yang dibangun masyarakat terhadap makam keramat mempunyai legitimasi untuk mengatur masyarakat, misalnya perilaku ulama yang semasa hidupnya selalu berdoa pada malam hari yang kemudian diikuti para pengikutnya (Chotib, 2015). 
Dalam perspektif lainnya, kegiatan yang dilakukan individu atau kolektif dalam menjalankan nilai-nilai agama disebut komunikasi transedental, yaitu komunikasi yang berlangsung di dalam diri dengan sesuatu di luar diri, yang disadari keberadaannya oleh individu karena adanya kesadaran tentang suatu esensi di balik eksistensi (Syam, 2015). Sebagai partisipan, manusia berupaya memahami tanda, simbol, dan lambang-lambang yang telah dihadirkan oleh Allah Swt. Pada konteks ini makam keramat menjadi sebuah simbol sebagai wujud mendekatkan diri kepada Tuhan (Sari, Wajdi \& Narulita, 2018).

Karomah sendiri dapat didekati lewat komunikasi transedental, yaitu kembalinya manusia ke alam sadar dengan mengakui agama sebagai problem solver dalam berbagai aspek kehidupan. Komunikasi transedental adalah komunikasi intrapersonal yang terjadi di dalam diri dengan sesuatu di luar diri yang keberadaanya disadari oleh individu. Atau dengan kata lain, komunikasi transedental adalah komunikasi yang berlangsung antara diri individu dengan sesuatu yang gaib.

Di Indonesia, komunikasi transedental kerap dilakukan secara kolektif sepanjang tahun. Komunikasi ini juga diadakan pada acara budaya yang tak terkait dengan upacara keagamaan, seperti upacara kelahiran, khitanan, pertunangan, perkawinan, syukuran dan kematian. Komunikator yang melakukan komunikasi transedental menegaskan untuk tetap selalu menjalankan dan menjaga nilai-nilai agama yang diimplementasikan dalam komunikasi transedental. Dalam menjalankan kegiatan ritual, seseorang atau siapa pun melakukannnya dengan emosional karena punya kepentingan yang sama. Komunikasi transedental merupakan ekspresi diri dan komunitas dalam mengungkapkan perasaan berbentuk verbal dan nonverbal. Ketika menjalani ritual tersebut, individu akan merasa nyaman akan perbuatan ritualnya tersebut.

Dalam konteks menziarahi makam keramat, wisatawan biasanya akan memohon agar dirinya dimuliakan Allah Swt. Wisata ziarah bertujuan untuk menyukuri kebesaran Tuhan dan berdoa agar sang arwah diterima oleh Tuhan Yang Maha Esa. Makam yang diziarahi bisa makam orangtua, makam keluarga atau makam yang dikeramatkan untuk mengirim doa, termasuk juga menziarahi tempat-tempat suci.

Sementara itu, pariwisata diartikan sebagai perpindahan orang untuk sementara dan dalam jangka waktu yang pendek ke tujuan di luar tempat di mana mereka biasanya hidup dan bekerja. Manusia secara individu atau kelompok pergi ke suatu tempat untuk memenuhi kebutuhan psikisnya mencari hiburan, kesenangan dan melupakan kepenatan sehari-hari dari rutinitas kerja. Karena manusia semakin banyak yang melakukan wisata, industri pariwisata tumbuh pesat baik di tingkat lokal, nasional, maupun internasional. Infrastuktur 
pariwisata berkembang untuk melayani para wisatawan. Bentuk dan objek wisata juga mengalami perkembangan yang pesat. Seiring kebutuhan manusia, destinasi wisata pun mulai beraneka ragam mulai dari wisata alam, budaya, kuliner hingga wisata religius.

Wisata religius sendiri adalah bagian dari potensi pariwisata yang dikembangkan oleh Pemerintah Provinsi Banten karena dapat mendorong kehadiran wisatawan untuk berziarah ke makam-makam keramat yang ada di Banten. Menurut Yoeti (1997), wisata religi memiliki daya tarik sebagai wisata budaya selain wisata alam dan khusus. Karena itu, pengelolaan objek wisata religius di Banten harus dilakukan secara profesional agar semakin berkembang serta menarik untuk wisatawan (Astuti \& Haryono, 2011; Machin \& Khoiruddin, 2017).

Dalam hal ini, promosi merupakan salah satu variabel dalam bauran pemasaran yang amat penting dalam kaitannya dengan pemasaran produk. Promosi merupakan arus informasi atau pesan yang dibuat untuk mengarahkan seseorang atau organisasi kepada tindakan yang menciptakan pertukaran. Kegiatan promosi dapat dilakukan salah satunya dengan menggunakan bauran komunikasi pemasaran (Sulaksana, 2007).

1. Periklanan, yaitu semua bentuk penyajian non personal dan promosi ide barang atau jasa yang dibayar oleh suatu sponsor tertentu.

2. Promosi penjualan, yaitu inisiatif-inisiatif jangka pendek guna mendorong keinginan mencoba atau membeli suatu produk jasa.

3. Hubungan masyarakat dan publisitas, yaitu berbagai program guna mempromosikan dan atau melindungi citra perusahaan atau produk individunva.

4. Penjualan personal, yaitu interaksi secara langsung dengan satu calon pembeli atau lebih guna melakukan presentasi, menjawab pertanyaan, menerima pesanan dan lain sebagainya.

5. Pemasaran langsung, yaitu penggunaan surat, telepon, e-mail, dan alat penghubung nonpersonal lain untuk berkomunikasi secara langsung dengan calon pelanggan atau untuk mendapatkan tanggapan/respon langsung dari pelanggan dan calon pelanggan.

\section{METODE PENELITIAN}

Penelitian ini merupakan riset kualitatif, menggambarkan sebuah perspektif atau informasi dari suatu masalah. Tipe penelitian ini adalah analisis kualitatif yang bersifat sistemis, subjektivis dan analitis. Teknik pengumpulan data penelitian ini menggunakan wawancara, observasi, dan studi pustaka. Teknik penentuan informan dengan purposive sampling, yaitu teknik pengambilan sampel dengan pertimbangan tertentu. Adapun jenis data yang digunakan dalam penelitian ini adalah data primer berupa pengumpulan data segala sesuatu yang 
berkaitan langsung dengan keberadaan situs Kesultanan Banten dan data sekunder dengan mempelajari serta mengkaji literatur-literatur yang terkait dengan permasalahan yang diteliti.

\section{HASIL DAN PEMBAHASAN}

\section{Bauran Komunikasi Pemasaran}

Kekuatan bauran komunikasi terletak pada pengetahuan masyarakat mengenai produk serta keseluruhan proses produksi dan penjualan (Bungin, 2015). Masyarakat sebagai sasaran yang ingin dibidik harus mendapatkan informasi mengenai produk serta keseluruhan poses produknya sehingga masyarakat dapat menikmati pelayanan jasa atau produk yang dikomunikasikan secara langsung atau tidak langsung. Dengan informasi yang diterima, masyarakat akan memahami setiap layanan dan agenda yang dilakukan produsen. Target utama bauran komunikasi adalah bagaimana informasi produk sampai ke konsumen. Bauran komunikasi pemasaran yang dilakukan dalam pengelolaan wisata religius Keraton Kesultanan Banten adalah menyampaikan informasi mengenai sejarah dari Kesultanan Banten, situssitus Kesultanan Banten, acara-acara ritual, Khaul Sultan Maulana Hasanudin setiap tanggal 29 Ramadan, tata cara dan adab berdoa dan berzikir, lokasi makam para sultan dan keluarga sultan, termasuk informasi sarana dan prasarana infrastruktur pendukung wisata religius Kesultanan Banten. Dinas Pariwisata Provinsi Banten, Dinas Pemuda, Olahraga dan Pariwisata Kota Serang serta Lembaga Pemangku Adat Kesultanan Banten merupakan organisasi inti yang mengkomunikasikan berbagai informasi Kesultanan Banten dalam ragam bentuk/format. Menurut Eka Purwanti, Kasi Pengembangan Ekonomi Kreatif Dinas Pemuda Olahraga dan Pariwisata Kota Serang, objek wisata di Provinisi Banten dibuat dalam bentuk poster, buku, pamflet, dan flyer.

Informasi mengenai Kesultanan Banten dalam konsep bauran komunikasi berinti pada dua faktor, yaitu informasi dari mulut ke mulut atau word and mouth dan identitas korporasi. Pesan dari mulut ke mulut adalah bentuk komunikasi yang dilakukan orang ke orang tanpa adanya nuansa komersial tentang produk, layanan, merek dan jasa. Pesan dari mulut ke mulut dilakukan oleh seseorang dengan cara memuji, mengomentari atau merekomendasikan berdasarkan pengalaman yang dilaluinya sehingga pembicaraan itu dapat memengaruhi orang lain untuk melakukan apa yang disampaikan.

Word of mouth adalah komunikasi dari orang ke orang antara sumber pesan dan penerima pesan di mana penerima pesan menerima pesan dengan secara tidak komersil mengenai suatu produk, pelayanan, atau merek. Lupiyoadi (2006) menyebutkan pesan dari mulut ke mulut merupakan bentuk promosi yang berupa rekomendasi dari mulut ke mulut tentang kebaikan dalam produk. Kotler dan Keller (2009) menekankan pesan dari mulut ke mulut 
adalah komunikasi lisan, tertulis, atau elekronik antarmasyarakat yang membicarakan keunggulan, pengalaman membeli atau menggunakan produk atau jasa.

Pengetahuan masyarakat mengenai objek pariwisata religius Kesultanan Banten diawali dari informasi mulut ke mulut. Informasi tentang berbagai aktivitas, sejarah, dan manfaat bila melihat Cagar Budaya Banten lama disampaikan individu kepada individu lain. Artinya, informasi mengenai Kesultanan Banten yang menyebar banyak dilakukan secara dari mulut ke mulut.

Situs Keraton Kesultanan Banten sendiri ialah bagian dari sejarah perkembangan Islam pada abad ke-16 di Indonesia pada umumnya dan di Pulau Jawa pada khususnya. Situs itu terdiri dari Istana Keraton Kaibon, Istana Keraton Surosowan, Masjid Agung Banten, Vihara Avalokistesvara, Benteng Spellwijk, Museum Kepurbakalaan Banten Lama, dan Danau Tasik Kardi (Asiti, 2016). Masjid Agung Banten Lama sendiri selesai dibangun pada 1556 di Barat Alun-alun. Masjid ini mempunyai serambi yang terdapat di empat sisi dan ruang utama dengan fungsi sebagai berikut: (1) Serambi Timur, yaitu tempat terluas dari empat serambi yang ada dengan atap yang terpisah dengan bangunan utama; (2) Serambi Selatan, digunakan sebagai tempat 15 makam para keluarga Sultan Banten; (3) Serambi Utara dan Selatan yang ada di bawah atap bangunan utama. Selain Masjid Agung Banten Lama ada pula masjid yang terletak di sebelah Barat yaitu Masjid Pecinan Tinggi yang berjarak 700 meter dan Masjid Pakojan yang terletak di tepi jalan Benteng Speelwijk dan Kampung Karangantu.

Destinasi wisata lainnya yang turut mengalami perkembangan di Banten adalah makam sebagai objek wisata ziarah, yang di Banten terdapat di 66 lokasi, di antaranya Makam Sultan Hasanudin, Makam Sultan Aliyudin, Makam Pangeran Aria Mandalika yang berada di Kecamatan Kasemen. Ketiga makam itu berjarak 10 kilometer dari pusat pemerintahan Kota Serang. Para peziarah wisata religius tak hanya mendatangi makam yang ada di Masjid Agung Banten Lama, tetapi juga di lokasi-lokasi lainnya.

Komplek makam keluarga Sultan Banten yang berada di serambi Selatan Masjid Agung Banten Lama menjadi salah satu tempat utama bagi para peziarah untuk berzikir, berdoa, dan mengajukan permohonan lainnya. Situs makam para Sultan Banten diyakini para peziarah bisa mengabulkan keinginan jamaah untuk ragam tujuan, seperti kenaikan jabatan, mencari jodoh, menenangkan diri, dan meningkatkan rezeki. Para peziarah atau wisatawan secara berkelompok akan berdoa antara 15-60 menit di dekat makam dengan dituntun oleh juru kunci.

Pengetahuan tentang sejarah Kesultanan Banten itu sendiri disampaikan kepada masyarakat lewat saluran formal seperti sekolah atau saluran informal seperti pengajianpengajian. Dari segi corporate, Kesultanan Banten memiliki identitas perusahaan, yaitu 
Menara Masjid Agung Banten yang berada di sisi Timur Masjid Agung Banten. Menara masjid menjadi simbol tentang identitas Kesultanan Banten. Menara tersebut dibangun pada 1620 oleh arsitek Belanda Hendrick Lucasz Cardeel pada masa kekuasaan Sultan Haji.Menara ini peruntukkannya ialah untuk mengumandangkan adzan serta mengawasi perairan laut. Sebagai identitas Menara Masjid Banten selalu dihadirkan dalam berbagai media promosi yang berkaitan dengan Kesultanan Banten.

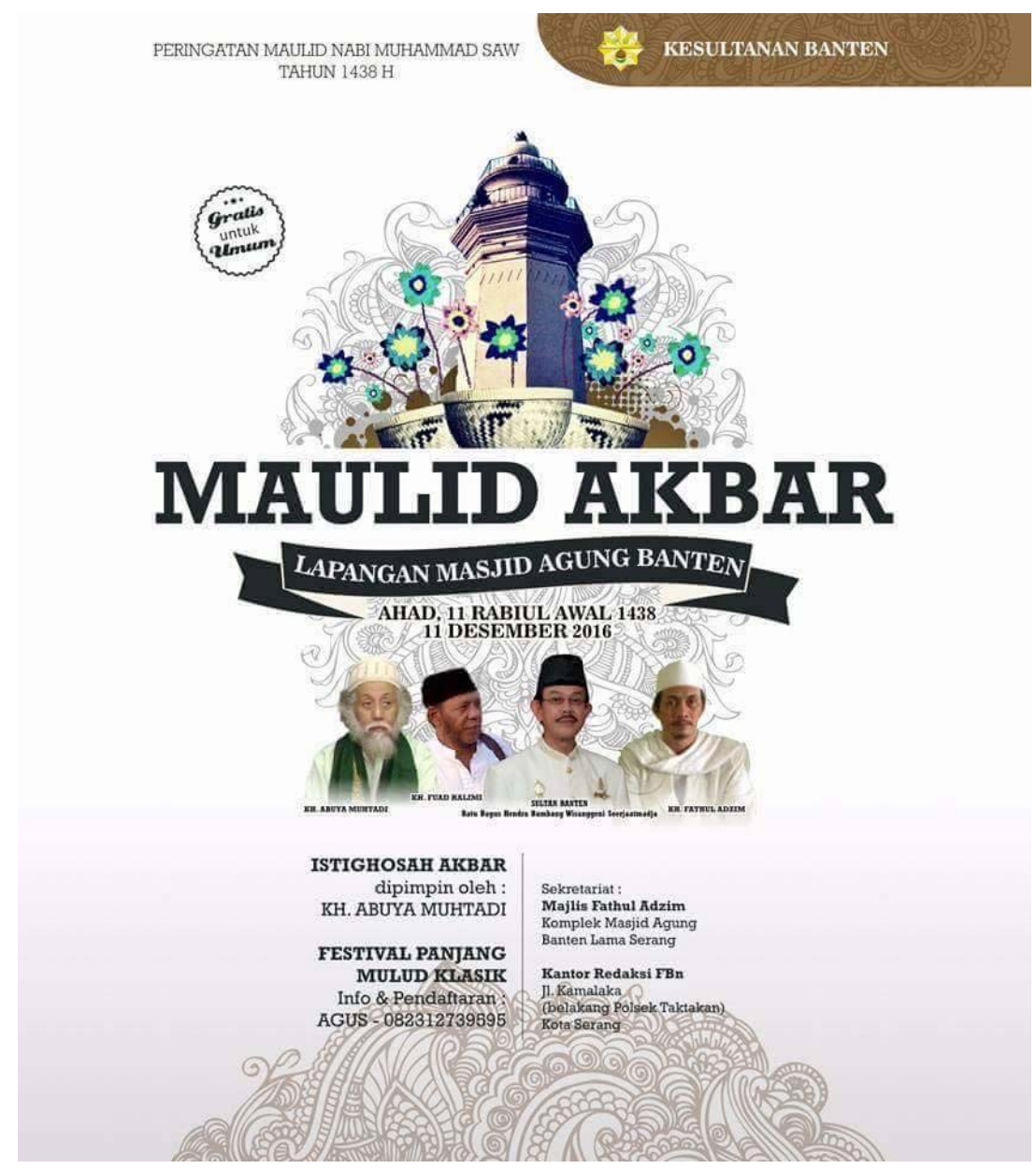

Gambar 1. Poster Menara Masjid Agung Banten sebagai Identitas

(Sumber: https://twitter.com/infomusicsrg/status/807767582417698817)

Pada konsep bauran komunikasi, pesan dari mulut ke mulut (word of mouth) dan adanya identitas Kesultanan Banten diimplementasikan dalam unsur bauran komunikasi pemasaran. Dari dua kunci bauran komunikasi pemasaran kemudian dilanjutkan dengan promosi penjualan, periklanan (advertising), humas, pemasaran langsung, dan penjualan personal. 


\section{Promosi Penjualan}

Promosi penjualan adalah kegiatan komunikasi untuk memperkenalkan sebuah produk/ jasa serta mendorong peningkatan permintaan masyarakat. Dengan melakukan promosi penjualan, masyarakat akan mengetahui berbagai keunggulan produk dan jasa serta dapat meningkatkan kepercayaan dan image publik pada produk dan jasa tersebut. Lembaga Adat Kesultanan Banten sendiri tak secara khusus melakukan promosi melalui media massa karena pertimbangan tingginya biaya pemasangan iklan. Karena itu, salah satu promosi penjualan yang dilakukan oleh Dinas Pariwisata Provinsi Banten adalah dengan menggelar berbagai pameran dan event.

Promosi dilakukan dengan mengadakan pameran atau event yang terkait dengan pariwisata di Provinsi Banten di mana situs Kesultanan Banten termasuk objek wisata yang dipromosikan. Karena yang dipasarkan adalah produk budaya, maka konten event yang dibuat harus kental nuansa budaya. Dinas Pemuda Olahraga dan Pariwisata Kota Serang pun membuat event budaya, pameran artefak gerabah atau parade budaya. Event yang dibuat diantaranya adalah Festival Surosowan pada 2017. Dengan berbagai event ini masyarakat akan lebih mengenal beragam budaya yang berkaitan dengan Kesultanan Banten (Anam, 2017; Rahma, 2017).

Sementara itu, Pameran Gerabah dilakukan dalam event-event tertentu. Gerabah adalah salah satu artefak yang sudah ada sejak masa lalu. Kini, pembuatan gerabah tetap dilakukan untuk meningkatkan ekonomi masyarakat setempat. Sebab itu, Dinas Pemuda Olahraga dan Pariwisata Kota Serang mengembangkan industri gerabah sebagai bagian dari peningkatan nilai pariwisata. Berbagai event tersebut diiklankan lewat media sosial, seperti Facebook, Twitter, Instagram (Generasi Pesona Indonesia atau GENPI) (Christin \& Marshal, 2016; Ri'aeni, 2015; Suryani, 2014). 
Tabel 1. Agenda Promosi Wisata Banten 2016-2018

\begin{tabular}{|c|c|c|c|c|}
\hline No & Penyelenggara & Event & Waktu & Tempat \\
\hline \multirow[t]{2}{*}{1} & Kesultanan Banten & Festival Panjang & 11 Desember & Masjid Agung \\
\hline & & Mulud Klasik & 2016 & Banten Lama \\
\hline \multirow[t]{3}{*}{2} & Dinas Pariwisata & Gebyar Wisata dan & 11-14 Mei 2017 & Jakarta \\
\hline & Propinsi Banten & Budaya Nusantara & & Conventions \\
\hline & & Ke-15 & & Center \\
\hline \multirow[t]{2}{*}{3} & Dinas Pariwisata & Banten Travel Mart & 19-21 April 2017. & Tanjung Lesung \\
\hline & Propinsi Banten & 2017 & & Beach Resort \\
\hline \multirow[t]{2}{*}{4} & Lembaga Adat & Festival Keraton & 9-12 November & Masjid Agung \\
\hline & Kesultanan Banten & Surosowan & 2017 & Banten \\
\hline \multirow[t]{2}{*}{5} & Dinas Pariwisata & Banten Expo 2017 & 16-18 November & ICE BSD \\
\hline & Propinsi Banten & & 2017 & Tangerang \\
\hline \multirow[t]{3}{*}{6} & Dinas Pariwisata & Gebyar Wisata dan & 10-13 Mei 2018. & Jakarta \\
\hline & Propinsi Banten & Budaya Nusantara & & Conventions \\
\hline & & Tahun 2018 & & Center \\
\hline \multirow[t]{3}{*}{7} & Dinas Pariwisata & Banten Travel & 28 April 2018 & Hotel Ultima \\
\hline & Propinsi Banten & Exchange & & Ratu Kota \\
\hline & & & & Serang \\
\hline
\end{tabular}

Sumber: Diolah dari Berbagai Sumber

Untuk mensukseskan pameran, panitia mengundang para pemangku kepentingan untuk ikut serta. Pada Festival Surosowan yang diadakan tanggal 9-12 November 2017 misalnya, panitia turut mengundang Sultan Sepuh XVI Cirebon, Kerajaan Boni Gowa Sulawesi Selatan, Kerajaan Galesong, Kerajaan Sekar Sorong Papua, Dewan Adat dari Kesultanan Gunung Tabur, Kedatuan Pejanggo Lombok, Kerajaan Kesultanan Sulu dan Borneo Utara, Kesultanan Indragiri, Kerajaan Karang Aceh, Kerajaan Malaka, Kerajaan Tonjong Sinjai Sulawesi Selatan, dan Kesultanan Kutai Kertanegara, Festival Keraton Surosowan diisi oleh berbagai macam kegiatan, seperti parade budaya, kesenian, atraksi khas Banten, kirab 500 prajurit, dan demo kolosal gerabah serta pameran potensi wisata yang ada di Propinsi Banten.

Promosi penjualan di antaranya menjual produk dan jasa pada masyarakat secara langsung. Pengelola Kesultanan Banten menjual dua jenis produk yang ditawarkan pada masyarakat. Pertama, menjual produk bernuansa Kesultanan Banten di toko atau gerai, seperti pada gerai souvenir Kesultanan Banten di Jalan Nyimas Saribanon Kota Serang. Produk yang dijual berasal dari berbagai UKM yang ada di Banten. Souvenir juga dijual di Griya Batik Banten dan Gerai Batik Pusaka Banten; berbagai motif batik yang dijual di antaranya ialah motif Benteng Surosowan, Sabakingking, Picis Banten, Umpak Labu, dan lain-lain. Sementara itu, ada sekitar 500 pedagang yang membuka lapak di sekitaran Masjid Agung Banten Lama. 
Untuk meningkatkan penjualan berbagai produk bernuansa Kesultanan Banten, dibuatkan pula pelatihan bagi warga yang terlibat dalam pengelolaan pariwisata. Untuk meningkatkan kualitas pelayanan pariwisata, Dinas Pemuda Olahraga dan Pariwisata Kota Serang membentuk Kelompok Sadar Wisata (Pokdarwis) supaya masyarakat lokal semakin sadar tentang pentingnya industri pariwisata, di mana masyarakat setempat bisa menjadi pemandu ziarah secara profesional yang bertugas menemani wisatawan tatkala berkunjung (Rodjinandari \& Supriadi, 2016; Sudipa, Rajeg \& Laksminy, 2014).

Sementara untuk meningkatkan omset penjualan produk bernuansa Kesultanan Banten, Dinas Pemuda Olahraga dan Pariwisata Kota Serang terus mengembangkan apa yang menjadi komponen pendukung industri pariwisata, misalnya pemasaran, destinasi, aksesibilitas, sumberdaya manusia, kelembagaan pariwasata, dan juga elemen yang lain sehingga dapat menjadi kesatuan produk pariwisata (Bungin, 2015).

Aksesibilitas adalah ketersediaan dan kemudahan sarana dan infrastruktur untuk mencapai lokasi wisata. Dinas Pariwisata Propinsi Banten sendiri terus meningkatkan aksesibilitas menuju kawasan Masjid Agung Banten Lama, yaitu dengan meningkatkan pembangunan infrastruktur. Kanal yang berada di lingkungan Banten Lama akan mulai difungsikan seperti semula sebagai sarana transportasi air. Proyek revitalisasi pada 2018 dilakukan dengan membebaskan 12 hektar lahan di sekitar Banten Lama.

Bentuk promosi penjualan berikutnya adalah merelokasi 500 pedagang kaki lima yang ada di sekitar Keraton Kesultanan Banten. Para pedagang akan ditempatkan pada lokasi khusus yang disediakan pemerintah. Bentuk yang ketiga adalah mendirikan pusat informasi pariwisata. Selanjutnya adalah menyediakan area parkir bagi bus. Selanjutnya adalah menyediakan fasilitas menginap (homestay). Selanjutnya adalah memperbanyak fasilitas kamar mandi/toilet. Terakhir, menyiapkan tempat ibadah salat. Ketujuh bentuk promosi penjualan tersebut diharapkan dapat semakin memperkenalkan destinasi wisata Kesultanan Banten kepada masyarakat luas.

\section{Iklan}

Berbagai pihak yang mengiklankan Kesultanan Banten adalah Dinas Pariwisata Propinsi Banten, Lembaga Pemangku Adat Kesultanan Banten, Dinas Pemuda Olahraga dan Pariwisata Kota Serang. Dinas Pariwisata Propinsi Banten sendiri mengiklankannya melalui media massa, media luar ruang, internet, brosur, dan media-media promosi yang lainnya. Dengan tagline 7 Wonders of Banten, disebutkan ada tujuh objek menarik yang memiliki nilai pariwisata tinggi, yaitu Masjid Agung Banten Lama, Suku Baduy, Taman Nasional Ujung Kulon, Pulau Sangiang, Pulau Umang, Gunung Krakatau, dan terakhir Rawadano. 
Melalui situs https://dispar.bantenprov.go.id/, masyarakat bisa mengakses aneka berita aktual mengenai kepariwisataan di Banten, tempat wisata di Banten, dan berbagai kebijakan yang terkait dengan kepariwisataan di Banten. Lewat upaya ini, objek wisata Banten Lama (yang mana di dalamnya terdapat Kesultanan Banten) bisa diketahui oleh masyarakat luas. Dalam hal ini, dapat dikatakan bahwa internet juga memegang peranan penting dalam mensosialisasikan beragam destinasi wisata yang ada di Banten (Basit \& Rahmawati, 2017; Indriyana, 2017; Atiko, Sudrajat \& Nasionalita, 2016; Yazid, 2015).

Tabel 2. Publikasi Masjid Agung Banten Lama

\begin{tabular}{|c|c|c|}
\hline No & Edisi & Judul Berita \\
\hline \multirow[t]{2}{*}{1} & 1 Agustus & Jokowi akan Berkunjung, Pemprov Bentuk Sekber Percepatan \\
\hline & & Revitalisasi Banten Lama \\
\hline 2 & 19 Juli & Revitalisasi Banten Lama Tahap Awal Ditarget Selesai November \\
\hline 3 & 20 Juni & Ini Objek Wisata di Banten yang Menarik Dikunjungi Saat Lebaran \\
\hline 4 & 12 Juni & Wisata Religi di Banten dan Jakarta, Jadi Inspirasi Libur Lebaran \\
\hline \multirow[t]{2}{*}{5} & 19 Mei & Kemenpar dan DMI Kembangkan Destinasi Wisata Religi Berbasis \\
\hline & & Masjid \\
\hline 6 & 14 Mei & Banten Kembali Memboyong Juara Stand Terbaik di GWBN 2018 \\
\hline 7 & $11 \mathrm{Mei}$ & Dispar Banten Jual Potensi Wisata Banten di Event Nasional \\
\hline 8 & 30 April & Fantastis, 200 Pax Paket Wisata Terjual di Banten Travel Exchange 2018 \\
\hline
\end{tabular}

Sumber: http://dispar.banten.go.id

Sementara itu, Dinas Pemuda Olahraga \& Pariwisata Kota Serang mengiklankan Masjid Agung Banten Lama dengan membuat Database Pariwisata Kota Serang Tahun 2015, yang berisi berbagai potensi destinasi wisata alam (pulau, terumbu karang, pantai, danau, gunung, cagar alam, hutan, air panas, air terjun), wisata buatan (agro wisata, desa wisata, heritage, situ, kolam renang), dan daya tarik minat khusus (wisata ziarah, arung jeram, dan goa). Dalam wisata ziarah, ada 66 makam keramat di Kota Serang.

\section{Humas}

Program humas dibuat untuk memperkuat identitas Keraton Kesultanan Banten sebagai objek wisata religius yaitu dengan menyebarkan informasi sehingga masyarakat dapat tertarik terhadap eksistensi Kesultanan Banten. Langkah itu dilakukan oleh Dinas Pemuda Olahraga dan Pariwisata Kota Serang serta Lembaga Adat Kesultanan Banten. Mengingat artefak peninggalan Kesultanan Banten berupa Benteng Kaibon, reruntuhan Keraton Surosowan, Menara Masjid Agung Banten serta Masjid Agung Banten menjadi magnet untuk 
para pengunjung, program kehumasan memanfaatkan media massa untuk memberitakan secara positif dan berkesinambungan agenda-agenda kegiatan Kesultanan Banten. Dengan mendapat liputan pemberitaan yang positif secara luas, berbagai agenda budaya dan ritual Kesultanan Banten akan meraih dukungan dari masyarakat.

Semenjak 2016, kelembagaan yang mengelola aktivitas Kesultanan Banten ialah Lembaga Pemangku Adat Kesultanan Banten (LPAKB) yang dibentuk berdasarkan SK Kemenkumham No. AHU 0072501.AH.01.07 tahun 2016. Visi lembaga yang dibentuk 12 keluarga Kesultanan Banten ini ialah untuk pengembangan dan revitalisasi kawasan Kesultanan Banten secara menyeluruh sekaligus bertanggung jawab menjaga nilai-nilai budaya peninggalan Kesultanan Banten. Melalui pembentukan LPAKB maka penguatan opini publik mengenai perlunya kelembagaan sebagai komponen komunikasi pariwisata yang memiliki badan hukum sudah terpenuhi (Bungin, 2015).

Guna meningkatkan publisitas Keraton Kesultanan Banten, setiap aktivitas harus mendapat liputan luas oleh media massa, termasuk aktif dalam organisasi resmi tingkat nasional. Oleh karena itu, Ketua LPAKB aktif dalam acara Forum Silaturahmi Keraton Nusantara (FSKN) yang dibentuk para raja, sultan, penglingsir dan pemangku adat guna mengembangkan nilai-nilai kearifan lokal warisan adilihung leluhur. Sementara posisi Ketua LPAKB dalam FSKN ialah sebagai Sultan Banten secara budaya. Melalui forum tersebut, eksistensi Keraton Kesultanan Banten sejajar dengan kesultanan/kerajaan yang ada di Indonesia sehingga dapat semakin menguatkan legitimasi organisasi, citra positif, dan dukungan dari public (Kholisoh \& Yenita, 2015).

Adapun kegiatan kehumasan lainnya adalah melakukan hubungan dengan media massa melalui konferensi pers. Festival Surosowan pada 9-12 November 2017 dianggap mampu mendongkrak jumlah kunjungan wisatawan yang datang ke Keraton Kesultanan Banten sebagai objek wisata budaya religi. Ketika festival diadakan, para wartawan ikut diundang oleh LPAKB untuk meliput acara tersebut. 
Tabel 3. Nama Media Peliput Konferensi Pers

\begin{tabular}{|c|c|c|c|}
\hline No & Nama Media & Judul Berita & Edisi \\
\hline 1 & www.newsmedia.com & $\begin{array}{l}\text { Ketika Raja dan Sultan se-Nusantara } \\
\text { Berkumpul di Keraton Surosowan } \\
\text { Banten, }\end{array}$ & $10 / 11 / 2017$ \\
\hline 2 & www.sindonews.com & $\begin{array}{l}\text { Festival Surosowan, Revitalisasi } \\
\text { Keraton Kesultanan Banten, }\end{array}$ & $6 / 11 / 2017$ \\
\hline 3 & www.bantenhits.com & Festival Surosowan Resmi Dimulai & $19 / 112017$ \\
\hline 4 & www.kabarbanten.com & $\begin{array}{l}\text { Festival Keraton Jadi Event } \\
\text { Internasional }\end{array}$ & $11 / 11 / 2017$ \\
\hline 5 & www.detiknews.com & $\begin{array}{l}\text { Banten Lama: Disegani Eropa, Punya } \\
\text { Uang Sendiri hingga Debus }\end{array}$ & $13 / 11 / 2017$ \\
\hline
\end{tabular}

\section{Sumber : Diolah dari Berbagai Sumber}

\section{Penjualan Personal}

Penjualan personal merupakan cara memasarkan sebuah produk dan jasa dengan cara berinteraksi langsung dengan calon pembeli/konsumen, dengan tujuan produk yang ditawarkan akan dibeli. LPAKB sendiri memiliki 300 pegawai yang bertugas mengelola dan mengatur operasional objek-objek wisata religius Kesultanan Banten, termasuk juga memelihara infrastruktur pendukung objek wisata Kesultanan Banten. Dari 300 pegawai tersebut sebanyak 20 pegawai bertugas membantu berdoa dan berzikir peziarah; mereka memberi layanan secara personal kepada para peziarah. Selain makam Sultan Maulana Hasanuddin, makam lainnya yang banyak dikunjungi ialah Kompleks Makam Kesenari, Kompleks Makam di Masjid Banten, makam-makam yang terletak di Kasunyatan, dan Makam Pangeran Mas (Astiti, 2006).

Para peziarah masuk ke dalam kompleks pemakaman untuk berdoa. Upacara doa dan zikir akan dipimpin oleh muzammir yang duduk di dekat batu nisan Makam Sultan Maulana Hasanudin. Untuk memasuki area kompleks makam, pengunjung tidak dikenai tarif khusus dan hanya membayar dengan sukarela. Di pintu masuk, ada kotak dari kayu berukuran $30 \mathrm{x}$ 30 sentimeter dengan tinggi setengah meter yang di atasnya ada lubang untuk memasukkan uang. Setiap pengunjung dipersilakan untuk mengisi kotak tersebut seikhlasnya. Bagi pengunjung yang tak mengisi kotak amal tetap dibolehkan masuk dan ikut berdoa. Secara keseluruhan terdapat 20 kotak yang disiapkan LPAKB yang tersebar di pintu masuk dan tempattempat strategis yang lainnya. 


\section{Pemasaran Langsung}

Pemasaran langsung ialah kegiatan menjual produk atau jasa ke pengguna akhir. Pemasaran secara langsung bisa dilakukan antara lain melalui surat, telepon, email, atau alat penghubung nonpersonal lainnya untuk berkomunikasi secara langsung dengan para pelanggan tertentu atau calon pelanggan. Dalam konteks manajemen wisata Kesultanan Banten, meskipun pemasaran langsung belum digunakan, peziarah atau wisatawan tetap datang ke Keraton Kesultanan Banten. Artinya, masyarakat luas telah mengetahui ihwal Kesultanan Banten meskipun tanpa dipromosikan. Hal ini terbukti dari jumlah peziarah atau wisatawan yang terus meningkat setiap tahunnya.

Sementara itu, para pemangku kepentingan juga saling memadukan kegiatan dan acaraacara yang diselenggarakan di Kesultanan Banten. Jadi, terdapat koordinasi antara Pemprop Banten, Dinas Pemuda Olahraga dan Pariwisata Kota Serang beserta Lembaga Pemangku Adat Kesultanan Banten dalam merealisasikan berbagai program yang sudah ada. Pada konteks manajemen kepariwisataan, para pemangku kepentingan itu bersuara sama, misalnya menyetujui rencana pemerintah propinsi merevitalisasi Kawasan Masjid Agung Banten Lama.

\section{KESIMPULAN}

Berdasarkan hasil penelitian ini, bauran komunikasi pemasaran (aspek filosofis, unsur keterkaitan antarunit kerja, keterpaduan berbagai fungsi dan peningkatan loyalitas pelanggan) yang diimplementasikan oleh manajemen wisata religius Kesultanan Banten belum diterapkan secara optimal. Periklanan, promosi penjualan, humas, dan penjualan personal dilakukan oleh Dinas Pariwisata Propinsi Banten, Dinas Pemuda Olahraga dan Pariwisata Kota Serang, dan Lembaga Pemangku Adat Kesultanan Banten. Periklanan, promosi penjualan dan humas dilakukan pada skala nasional dengan mengiklankan pada media nasional, mengikuti pameran budaya nasional, serta ikut melibatkan Kementerian Pariwisata. Fungsi kehumasan telah dijalankan dengan melibatkan media nasional untuk mempublikasikan kegiatan Gubernur Banten dan Ketua LPAKB dalam setiap kegiatan yang diselenggarakan Kesultanan Banten. Pemasaran secara langsung juga masih belum dilakukan, karena Kesultanan Banten sebagai wisata religius telah diketahui masyarakat luas.

Sementara itu, kondisi kawasan Masjid Agung Banten Lama sendiri belum dapat mencerminkan standarisasi objek wisata nasional, seperti lingkungan yang kumuh, tidak bersih, banyak pengemis, adanya pungutan parkir liar, dan akses jalan kurang memadai. Hal ini menandakan bahwa pemangku kepentingan belum menjalani bauran komunikasi pemasaran secara maksimal. Adapun implementasi bauran komunikasi pemasaran akan 
dijalankan secara maksimal setelah program revitalisasi Kawasan Banten Lama (2017-2020) selesai direalisasikan oleh Pemerintah Propinsi Banten.

\section{REFERENSI}

Anam, Mochammad Musafa'ul. (2017). “Strategi Ikonik Wisata untuk Memperkenalkan Kota Malang sebagai Salah Satu Destinasi Wisata Religi". Jurnal Pariwisata Pesona, 2(2): 111.

Anwar, Muhammad Fahrizal, Djamhur Hamid dan Topowijono. (2017) "Analisis Dampak Pengembangan Wisata Religi Makam Sunan Maulana Malik Ibrahim dalam Kehidupan Sosial dan Ekonomi Masyarakat Sekitar (Studi pada Kelurahan Gapurosukolilo Kabupaten Gresik)". Jurnal Administrasi Bisnis (JAB), 44(1): 186-193.

Astiti, Ni Komang Ayu. (2016). "Pengolahan Kawasan Situs Kuno Banten Sebagai Destinasi Wisata Budaya untuk Meningkatkan Pergerakan Wisatawan Nusantara". Jurnal Destinasi Kepariwisataan Indonesia, 1(1): 1-26.

Astuti, E. Puji dan R.V. Haryono. (2011). “Pengembangan Obyek Wisata Ziarah Makam Ki Ageng Balak dalam rangka Meningkatkan Kunjungan Wisatawan di Kabupaten Sukoharho". Jurnal Pariwisata Indonesia, 7(1): 1-20.

Atiko, Gita, Ratih Hasanah Sudrajat, Kharisma Nasionalita. (2016). “Analisis Strategi Promosi

Pariwisata melalui Media Sosial oleh Kementerian Pariwisata RI (Studi Deskriptif pada Akun Instagram @ Indtravel)”. Jurnal Sosioteknologi, 15(3): 378-389.

Basit, Abdul dan Tri Herni Rahmawati. (2017). “Cyber Public Relations (E-PR) dalam Brand Image Wardah Kosmetik dengan Pedekatan Mixed Method". Nyimak Journal of Communication, 1(2): 197-208.

Bungin, Burhan. (2015). Komunikasi Pariwisata: Pemasaran dan Brand Destinasi. Jakarta: Prenada Media Group

Chotib, Moch. (2015). "Wisata Religi di Kabupaten Jember". FENOMENA, 14(2): 407-428.

Christin, Maylanny dan Tito Marshal. (2016). "Aktivitas Humas Bercerita dalam Pariwisata (Aktivitas Cyber Public Relations Akun Instagram Ceritapadang dalam Pembangunan Pariwisata Minangkabau)". Prosiding Seminar Nasional Komunikasi 2016.

Cornelissen, Joep. (2018). Corporate Communication. Los Angeles: Sage Publications.

Damardjati, R. (1995). Istilah-Istilah Dunia Pariwisata. Jakarta: Paradnya Paramita.

Dinas Pemuda, Olahraga dan Pariwisata Kota Serang. (2015). Database Pariwisawa Kota

Serang. Banten: Dinas Pemuda, Olahraga dan Pariwisata Kota Serang.

Hasan, Ali. (2010). Marketing dari Mulut ke Mulut. Yogyakarta: Media Pressindo. 
Indriyana, Nitiya. (2017). “Aktivitas Cyber Public Relations dalam Mempromosikan Destinasi Wisata di Kawasan Indonesia Timur". Seminar Nasional Procen 2017.

Kholisoh, Nur dan Yenita. (2015). "Strategi Komunikasi Public Relations dan Citra Positif Organisasi (Kasus Public Relations Rumah Sakit "X" di Jakarta)". Jurnal IImu Komunikasi, 13(3): 195-209.

Kotler, Philip dan Kevin Lane Keller. (2009). Manajemen Pemasaran (Jilid 1). Jakarta: Erlangga. Lupiyoadi, Hamdani. (2006). Manajemen Pemasaran Jasa. Jakarta: Salemba Empat.

Machin dan Khoiruddin. (2017). “Pengembangan Potensi Wisata Religi Oleh Pemerintah Daerah Kabupaten Jombang (Studi di Kawasan Wisata Religi Makam KH. Abdurrahman Wahid)". Jurnal @Trisula, 4(2): 468-477.

Rahma, Ade. (2017). “Event Sebagai Salah Satu Bentuk Strategi Komunikasi Pemasaran Produk Fashion Nasional (Event Tahunan Jakcloth)". Nyimak Journal of Communication, 1(2): 149-169.

Ri'aeni, Ida. (2015). “Penggunaan New Media dalam Promosi Pariwisata Daerah Situs Cagar Budaya di Indonesia". Jurnal Komunikasi, 9(2): 187-197.

Rodjinandari, Nanny dan Bambang Supriadi. (2016). "Kompetensi Pendampingan Pemandu Wisata Lokal sebagai Developers of People". Jurnal Pariwisata Pesona, 2(1): 72-86.

Rohman, Auliyaur dan Moh. Qudsi Fauzi. (2016). “Dampak Ekonomi terhadap Pendapatan Pedagang Kios di Wisata Religi Makam Sunan Drajat Lamongan". Jurnal Ekonomi Syariah Teori dan Terapan, 3(2): 114-126.

Saefullah, Ujang. (2007) Kapita Selekta Komunikasi. Bandung: PT. Remaja Rosdakarya. Sari, Nur Indah, Firdaus Wajdi dan Sari Narulita. (2018). “Peningkatan Spiritualitas melalui Wisata Religi di Makam Keramat Kwitang Jakarta". Jurnal Studi Al-Qur'an, 14(1): 44-58. Sudipa, I. N., I. M. Rajeg dan Lp. Laksminy. (2014). "Pelatihan Bahasa Inggris Pemandu Wisata Lokal di Desa Kapal”. Udayana Mengabdi, 13(2): 92-95.

Sulaksana, Uyung. (2007). Integrated Marketing Communications. Yogyakarta: Pustaka Pelajar. Surahman, Sigit. (2016). “Determinisme Teknologi Komunikasi dan Globalisasi Media Terhadap Seni Budaya Indonesia”. Jurnal Rekam, 12(1): 31-42.

Suryani, Ita. (2014). “Pemanfaatan Media Sosial sebagai Media Pemasaran Produk dan Potensi Indonesia dalam Upaya Mendukung ASEAN Community 2015. (Studi Social Media Marketing Pada Twitter Kemenparekraf RI dan Facebook Disparbud Provinsi Jawa Barat)". Jurnal Komunikasi, 8(2): 123-138.

Syam, Nina Winangsih. (2015). Komunikasi Transedental. Bandung: PT. Remaja Rosdakarya. Widagdo, Ridwan dan Sri Rokhlinasari. (2017). “Dampak Keberadaan Pariwisata Religi terhadap Perkembangan Ekonomi Masyarakat Cirebon". Al-Amwal, 9(1): 59-76. 
Yazid, Tantri Puspita. (2015). “Implementasi Cyber Public Relations Melalui Pengelolaan Website Pemerintah Provinsi Sumatera Barat". Jurnal Ilmu Komunikasi, 6(2): 113-190. Yoeti, Oka A. (2008). Pengantar Ilmu Pariwisata. Bandung: Angkasa. 
